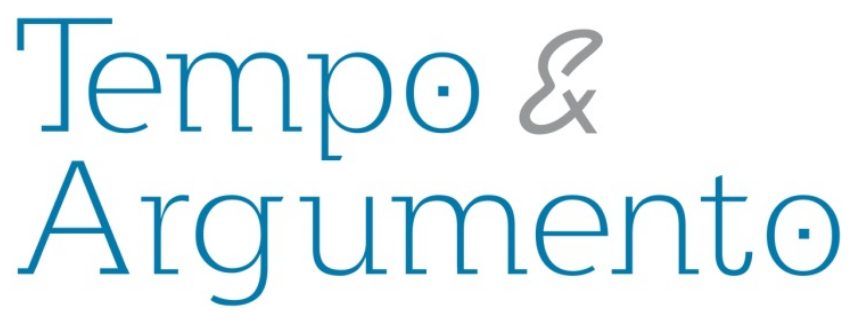

\title{
Testemunhos em perspectiva: uma análise das narrativas de vítimas da ditadura e a atuação da Comissão Estadual da Verdade no Oeste do Paraná
}

\begin{abstract}
Resumo
Esta pesquisa tem como objetivo realizar uma análise dos trabalhos da Comissão Nacional da Verdade no Brasil, instituída em maio de 2012 pela Presidenta Dilma Rousseff. Pautamo-nos em uma análise documental do relatório final publicado pelos membros desta Comissão em dezembro de 2014, seu cotejamento dos depoimentos prestados em audiências públicas promovidas pela CNV na cidade de Cascavel - PR, bem como com entrevistas posteriormente realizadas com depoentes destas audiências, tendo por objetivo compreender como se dá a construção das memórias desses sujeitos em relação ao passado e ao presente, atentando também para o modo como estas memórias são trabalhadas pela Comissão. Esta etapa consiste numa fase inicial de um projeto mais amplo, que se baseia em revisitar os depoentes das audiências da CNV realizadas em Cascavel, produzindo novas entrevistas e adentrando em percepções mais amplas e ligadas às suas trajetórias de vida cotejando as mesmas às experiências testemunhadas com relação à ditadura civil-militar brasileira. Nesta perspectiva levantamos algumas perguntas: como a CNV percebe essas relações entre passado e presente na construção dos depoimentos prestados? De que maneira a construção das entrevistas e do próprio ambiente das audiências influencia nos depoimentos? De que modo as narrativas coletadas são transportadas para os relatórios finais? Entre outras questões.
\end{abstract}

Palavras-chave: Memória. Vitimização. Comissão Nacional da Verdade.

\author{
Marcelo Hansen Schlachta \\ Doutorando em História pela Unioeste. \\ Professor de História no Instituto Federal do \\ Paraná (Campus Cascavel). \\ Brasil \\ marcelo.hansen@yahoo.com.br
}

\footnotetext{
Para citar este artigo:

SCHLACHTA, Marcelo Hansen. Testemunhos em perspectiva: uma análise das narrativas de vítimas da ditadura e a atuação da Comissão Estadual da Verdade no Oeste do Paraná. Revista Tempo e Argumento, Florianópolis, v. 9, n. 20, p. 267 - 307. jan./abr. 2017.
} 


\title{
Testimonials in Perspective: an analysis of the stories by the victims of the dictatorship and the action of the National Truth Commission in the West of
}

\section{Parana.}

\begin{abstract}
This work aims an analysis on the work performed by the National Truth Commission (NTC) in Brazil, enacted in May 2012 by the president Dilma Rousseff. This analysis was based on the final report issued by the Commission in December 2014, as well as the comparison of the testimonials given in public judgments held by the NTC in the city of Cascavel - Parana. Along with those are the interviews given by the deponents of these judgments, aiming to understand how the memory of these subjects is formed regarding the past and the present, with special attention to the manner this memory is worked by the NTC. This stage consists of an initial phase of a wider project, which is intended to review the deponents of the judgments held in Cascavel by the NTC, producing new interviews, and entering a bigger scope of perceptions connected to their life experiences, confronting these same experiences to the ones regarding the Brazilian Military Dictatorship. By these means, an initial question is raised of how the NTC notices the relation between the past and the present on the making of the testimonials given, how the way that the interviews are made and the environment in which they happen influences on the testimonials, in which way the collected stories are transferred to the final reports, and if it would be necessary to forget something to remember, among other issues.
\end{abstract}

Keywords: Memory. Victimization. National Truth Commission. 


\section{Apontamentos iniciais}

A Comissão Nacional da Verdade (CNV) desenvolveu intensos trabalhos no que tangenciam as memórias acerca do período militar que foram suprimidas. Nesse sentido, o objetivo deste trabalho consiste em pensar o modo pelo qual se estrutura a construção dessa memória, tomando por base os relatórios Nacional e Estadual, tendo por foco o Oeste do Paraná. Trata-se, pois, de proceder metodologicamente uma análise das representações acerca das noções de verdade, esquecimento, mentira e outras, que orientam os trabalhos das Comissões (Nacional e Estadual), situando historicamente o debate acerca da articulação dessas memórias no lugar material que lhes é correspondente, bem como pensando a estruturação de alguns depoimentos em relação à estrutura montada nas audiências públicas ocorridas em Cascavel - PR.

Esta etapa consiste numa fase inicial de um projeto mais amplo, que se baseia em revisitar os depoentes das audiências da CNV realizadas em Cascavel, produzindo novas entrevistas e adentrando em percepções mais amplas e ligadas às suas trajetórias de vida cotejando as mesmas às experiências testemunhadas com relação à ditadura civil-militar brasileira. Nesse sentido, esta pesquisa tem por objetivo compreender como se dá a construção das memórias desses sujeitos em relação ao passado e ao presente, atentando também para o modo como estas memórias são trabalhadas pela Comissão.

Entendemos que a entrevista é uma construção intersubjetiva na qual se delineia uma relação entre um indivíduo, que a partir de suas concepções permeadas de subjetividade lança questionamentos, e outro que a partir de suas percepções responde a estas indagações. Assim, dialogamos com a perspectiva de Beatriz Sarlo ao delinear que

a memória permite a relação do corpo presente com o passado e, ao mesmo tempo, interfere no processo "atual" das representações. Pela memória o passado não só vem à tona das águas presentes, misturandose com as percepções imediatas, como também empurra, "desloca" estas últimas, ocupando o espaço todo da consciência. A memória aparece como força subjetiva ao mesmo tempo profunda e ativa, latente e penetrante, oculta e invasora. (SARLO, 2007: 93)

Nesta perspectiva, levantamos algumas perguntas: como a CNV percebe essas relações entre passado e presente na construção dos depoimentos prestados? De que 
necessidade do pesquisador posicionar-se frente à memória, haja vista que, muitas vezes, o indivíduo silencia acerca do passado, talvez como uma espécie de proteção, por crer que é o melhor naquele momento - o que não representa necessariamente um ato de esquecimento. Nesse sentido, não devemos visualizar a memória como sendo indissociável da organização social da vida, uma vez que possibilita algumas pessoas falar sobre determinado fato em detrimento de outras.

Na obra O Tempo Passado, Beatriz Sarlo pondera sobre a maneira como as Comissões da Verdade delineiam ambientes propícios para um determinado modelo de narrativas, as quais privilegiam testemunhos que se pautam nas violações de direitos, estimulam narrativas vitimizadoras e, por vezes, desconsideram suas trajetórias de vida em relação à ditadura, impossibilitando uma plena reconciliação dos sujeitos com o seu passado. Assim, cotejando estas ideias com as perspectivas de Alessandro Portelli, que visualiza a subjetividade presente nas narrativas orais como algo que, se analisado de modo mais complexo, revelará algo para além das realidades objetivas, uma vez que "a maior riqueza, a maior contribuição cognitiva que chega a nós das memórias e das fontes orais. [...] não temos, pois, a certeza do fato, mas apenas a certeza do texto: o que nossas fontes dizem pode não haver sucedido verdadeiramente, mas está contado de modo verdadeiro" (PORTELLI, 1996: 4).

Outra perspectiva que também orienta as análises vindouras encontra-se em James C. Scott em sua obra A Dominação e Arte da Resistência - Discursos Ocultos (2013) que faz uma crítica ao poder restrito ao Estado, mostrando como outros espaços sociais são portadores de resistência ao adentrarem no cotidiano da classe trabalhadora e pensarem o sentido político da resistência.

A experiência narrada pelo sujeito traz em si possibilidades de tornar o passado presente, aflorar sensibilidades, sentimentos, opiniões, que permitem ao pesquisador lançar olhares sobre as diversificadas possibilidades acerca da vida humana. Assim, as subjetividades são reinventadas no ato de narrar a si. Paul Ricoeur (2007: 101) pontua que 
o historiador deve ter como preocupação central não a constituição de uma história que se pretenda objetiva, mas uma história nutrida por uma boa subjetividade.

Nesse sentido, a relação entre História e memória é desenhada a partir de um conjunto de aproximações e distanciamentos, debates sobre imparcialidade e neutralidade, especialmente no que concerne ao ofício do historiador no trato com as memórias. Desta feita, os trabalhos desenvolvidos pelas Comissões da Verdade conseguem promover um modelo pleno na constituição de uma memória das vítimas da ditadura? As ações até então desenvolvidas contribuem no processo de reconciliação dos sujeitos consigo mesmos, com o seu passado e com os outros? Os diálogos entre presente e passado são interpretados de que modo pela Comissão? Estas são algumas perguntas que demarcam os primeiros passos deste trabalho.

\section{A Comissão da Verdade em seu lugar material correspondente}

Uma ideia de certo modo naturalizada por alguns paranaenses é a de que no Paraná a ditadura militar praticamente não foi sentida, que prisões foram raras, que não houve movimentos de resistência e que violações aos direitos humanos não existiram, diferente de grandes centros como Rio de Janeiro, São Paulo, Minas Gerais etc. Tal afirmação se dá em uma perspectiva que reforça a concepção de uma colonização e ocupação ordeira, pautada nas ações de companhias colonizadoras e do papel do Estado, bem como nas concepções ligadas à maciça presença de imigrantes que vieram para a região com uma mentalidade ordenada pelo trabalho e progresso'.

A própria literatura histórica mais tradicional muitas vezes parece imputar uma irrelevância aos episódios paranaenses, pois produz uma narrativa histórica que sugere o entendimento de uma ditadura branda no Paraná. Para Marionilde Dias Brehpol de Magalhães, uma ideia de senso comum bastante generalizada entre os paranaenses é a de uma população ordeira e pacata (MAGALHÃES, 2001: 89). Nesse mesmo sentido, a historiadora Carla Conradi, avalia que esse senso comum, não raras vezes, leva muitas

\footnotetext{
${ }^{1}$ Não se faz objetivo desta pesquisa, pelo menos até o presente momento, uma análise mais detalhada de como se constroem as memórias e culturas de história nos espaços fora dos círculos acadêmicos, bem como fora dos círculos de ex-presos e perseguidos políticos e seus familiares.
} 
pessoas a enxergarem as resistências e a repressão como algo próprio da realidade de outros Estados, uma vez que "o Paraná por ter um suposto perfil político de direita e conservador, teria se alinhado ao governo militar, desde a instauração do golpe em 1964, sem muita resistência, tanto na esfera governamental quanto pela sua sociedade civil” (CONRADI, 2015: 154-155).

Essa perspectiva é bastante reforçada quando tratamos das regiões Oeste e Sudoeste do estado, áreas estas, por certo, ocupadas mais tardiamente em relação às outras regiões e com a presença intensa de migrantes sulistas - mais comumente de origem italiana e alemã - e alvo da ação de grandes companhias colonizadoras².

Nesse sentido, conforme fora observado na dissertação de mestrado O MST e a Questão Agrária: uma cultura política em movimento (2008), tanto a historiografia tradicional, quanto os meios de comunicação social, são portadores de uma forte tendência a negligenciar as irregularidades ao longo do processo de colonização, bem como ocultar a existência de conflitos que existem até os tempos atuais, o que demonstra que a ocupação e o desenvolvimento regional não se deram tão pacificamente como muitas vezes se procura fazer crer.

$\mathrm{Na}$ esteira dessas constatações, podemos evidenciar que durante as décadas de 1960 e 1970, durante a ditadura civil-militar, a política de modernização agrária foi um dos principais projetos estimulados pelo governo e que encontrava ampla consonância com os projetos das políticas colonizadoras, bem como com a mentalidade de muitos migrantes que aqui se estabeleceram, contribuindo para a construção de uma memória hegemônica acerca do Oeste paranaense e sobre a ditadura no interior do Brasil.

Todavia, embora não tão visíveis, as ações promovidas dentro do regime de Estado de exceção foram portadoras de elevado grau de violência, tanto física quanto

\footnotetext{
${ }^{2}$ Um pouco sobre essa visão "ordeira" acerca do processo de ocupação do Oeste paranaense, bem como trazem silêncios ou uma visão pacífica sobre o período da ditadura civil-militar pode ser encontrado nas seguintes obras: SPERANÇA, Alceu A. Cascavel: A História. Curitiba. Lagarto, 1992.; NIEDERAUER, Ondy H. Toledo no Paraná - História de um latifúndio improdutivo, sua reforma agrária, sua colonização, seu progresso. Toledo. Grafo-Set. 1992; COLODEL, Augusto. Obragens \& Companhias Colonizadoras - Santa Helena na História do Oeste Paranaense até 1960. Santa Helena: Prefeitura Municipal, 1988; CIRIO, Dom Armando. Arquidiocese de Cascavel: Ontem e Hoje - 1978-1983. Assoeste, Cascavel, 1983; PAWELKE, J. Ficando rico no Oeste do Paraná. Marechal Cândido Rondon: Igreja Martin Luther, 1970; SAATAKAMP, Venilda. Desafios, lutas e conquistas: História de Marechal Cândido Rondon. Cascavel: Assoeste, 1984.
} 
simbólica, voltando-se normalmente para uma camada da população que poucos meios teve para sua defesa e sob a qual o silenciamento contribuiu para operar a consolidação de uma memória harmônica acerca do passado regional.

Populações camponesas, comunidades indígenas, quilombolas, posseiros, colonos, entre outros, por não possuírem uma mentalidade e um conjunto de práticas que se adequassem à noção de progresso pretendida como forma de ampliação da fronteira agrícola nacional, ou por realmente se encontrarem no caminho de grandes empresas e latifundiários, foram objetos de expulsão e de formas variadas de violação físicas, psicológicas, de direito, entre outras - durante o período.

Os reflexos do projeto de modernização foram bastante intensos, haja vista o claro aumento das populações urbanas, juntamente com a mecanização as lavouras, e por consequência, com o incremento da produtividade. No entanto, válido é mencionar que o referido projeto trouxe consigo impactos altamente nocivos para alguns grupos locais, que elevou a violência na região.

O panorama até aqui delineado demonstra que a história regional no Oeste do Paraná ao longo do período ditatorial não foi tão harmônica quanto se propaga. Entretanto, devemos atentar para o fato de que no Oeste e Sudoeste do estado, tivemos também a ação de militantes-do MR8, da VAR-Palmares, do PCB, Grupos dos Onze etc. contra o governo militar.

Acerca do silêncio que paira sobre a ditadura na região Oeste/Sudoeste, Aluízio Palmar pontua que:

Construiu-se a sociedade do medo e do silêncio, onde prevalece o calarse e fingir que não aconteceu, ou que todos os crimes divulgados fazem parte de ideologias partidárias ou resquícios de ações 'comunistas'. Este silêncio brasileiro, também revela a própria dificuldade das pessoas falarem sobre o assunto por ser algo que as toca de uma forma negativa, pois o que é humano atinge, fere, mesmo sem que a pessoa seja testemunha ocular dos fatos. Mais do que isso, admitir que o horror aconteceu aqui também implicaria assumir parcela de culpa que cada um tem: culpa por trancarem-se em suas casas e preocuparem-se apenas com sua rotina, mesmo vendo seus vizinhos serem presos, sumirem ou serem mortos. (PALMAR in: SILVA, 2014: 153) 
No tocante ao golpe e ao desenvolvimento da ditadura civil-militar vários autores já debateram a participação do estado do Paraná sob diferentes prismas: os movimentos sociais que se estruturaram, o movimento estudantil, os partidos políticos e as organizações de esquerda, tal qual as perseguições, a repressão e as violações praticadas. Partindo das formulações até aqui apresentadas a Comissão da Verdade atuaria, no nível regional, de modo a trazer à tona uma outra memória a qual se encontra abafada na maioria das vezes.

Nesse sentido, a CNV foi instaurada no país em 2011 com o objetivo de apurar e esclarecer as violações aos Direitos Humanos ocorridas no período de 1946 a 1988, com a finalidade de garantir direito à memória, dando voz a sujeitos que foram silenciados ao longo do processo histórico, bem como promover a reconciliação nacional. O Governo do Estado do Paraná, por intermédio da Lei 17.362, de 27 de novembro de 2012, criou a Comissão Estadual da Verdade (CEV-PR), cujo objetivo reside em contribuir com a Comissão Nacional e examinar os graves casos de violações aos direitos humanos ocorridos no estado. Nesse sentido, orientado pelo Plano Nacional de Direitos Humanos (PNDH3), que pontua o "direito à memória e à verdade", uma série de trabalhos foram iniciados, tendo em vista compreender variadas situações de violência, expropriação e silenciamento de inúmeros sujeitos sociais. Assim, foram realizadas várias audiências públicas, promovendo a oitiva de vítimas, testemunhas e familiares de vítimas da ditadura civil-militar que se estabeleceu no Brasil no período de 1964-85.

Uma primeira leitura dos depoimentos prestados nas audiências de Cascavel e a maneira pela qual se encontram apresentados no Relatório Final da CEV-PR acenam para a construção de uma memória da resistência, trazendo à tona os casos de violação e as graves denúncias contra o terrorismo de Estado. Todavia, o espaço dado para o desenrolar dos testemunhos - salvo algumas exceções - orbitava em torno de aproximadamente dez minutos e os meios de sua publicização poderiam não ser os mais fecundos, em razão, até mesmo, da dificuldade de conseguir espaços mais amplos jornais, rádio, tv etc.

O relatório final apresentado pela CEV-PR pontua que o trabalho desempenhado “incitou-nos a refletir sobre e contra o esquecimento, como também sobre a verdade, 
colocando-nos, assim, face a face com a ditadura civil-militar", bem como pensar acerca do dever de investigar e punir os crimes cometidos em nome do "terror de Estado". O documento, em sua introdução segue afirmando acerca da necessidade de um compromisso com a memória e com a justiça, como observamos no excerto abaixo:

\begin{abstract}
A mentira e o esquecimento, ao contrário, potencializam a injustiça e produzem violência até mesmo maior do que a que foi promovida sobre os corpos e as mentes daquelas pessoas que resistiram ao golpe civilmilitar e à ditadura que com ele se instalou no Brasil. $O$ direito à verdade e à memória desafia a linearidade do tempo ao permitir a sua reversibilidade, de forma que aquilo que foi dito pode ser desdito, assim como aquilo que foi feito pode ser desfeito. No contexto de uma comissão de verdade a narrativa dos fatos pelas vítimas, seus familiares, como também pelos seus algozes, permite a reconstrução do passado em outros termos que não aquele narrado oficialmente pelo Estado, em circunstâncias de um verdadeiro terrorismo de Estado e da obliteração da verdade, em nome de razões forjadas na exceção do direito, da política e da justiça. (CEV-PR, 2014: 20)
\end{abstract}

O fragmento acima se apresenta construído de uma forma curiosa e cercado de uma série de signos que remetem a representações político-ideológicas. Ao afirmar que “aquilo que foi dito pode ser desdito", parte da presunção de que uma memória pode simplesmente substituir a outra, negligenciando, assim, que a memória é um campo de conflitos e permeado de disputas pela sua efetivação. Outro ponto interessante é o modo pelo qual o texto se edifica, servindo-se de elementos que traduzem uma série de aspirações acerca da memória que se objetiva conceber, permeada de uma dimensão política sobre a verdade, a memória, o esquecimento, uma vez que projetam valores socialmente compartilhados, atribuindo significado a determinadas situações e ações.

Outrossim, diante da impossibilidade de reconstrução plena do passado, o sujeito acaba por realçar a subjetividade, particularizando a construção dos discursos sobre este passado, não sendo lembrado despretensiosamente, mas se prestando a algum objetivo que se encontra além de simplesmente narrar o que já passou.

As relações entre memória e história já foram objeto de intensos debates entre variados autores. Cabe, então, citar em caráter instrutivo um trecho que, embora longo, traz uma perspectiva bastante interessante de como memória e história se relacionam 
em meio a um campo conflitivo e de constantes tensões acerca do passado. Nesse sentido Pierre Nora, na obra Entre memória e História: a problemática de lugares irá discorrer sobre a complexidade das tensões, distanciamentos e interações presentes nessa relação:

Memória, história: longe de serem sinônimos, tomamos consciência que tudo opõe uma à outra. A memória é vida, sempre carregada por grupos vivos e, nesse sentido, ela está em permanente evolução, aberta à dialética da lembrança e do esquecimento, inconsciente de suas deformações sucessivas, vulnerável a todos os usos e manipulações, susceptível de longas latências e de repentinas revitalizações. A história é a reconstrução sempre problemática e incompleta do que não existe mais. A memória é um fenômeno sempre atual, um elo vivido no eterno presente; a história, uma representação do passado. Porque é afetiva e mágica, a memória não se acomoda a detalhes que a confortam; ela se alimenta de lembranças vagas, telescópicas, globais ou flutuantes, particulares ou simbólicas, sensível a todas as transparências, cenas, censura ou projeções. A história, porque operação intelectual e laicizante, demanda análise e discurso crítico. A memória instala a lembrança no sagrado, a história a liberta, e a torna sempre prosaica. A memória emerge de um grupo que ela une, o que quer dizer como Halbwachs o fez, que há tantas memórias quantos grupos existem; que ela é, por natureza, múltipla e desacelerada, coletiva, plural e individualizada. A história, ao contrário, pertence a todos e a ninguém, o que lhe dá uma vocação para o universal. A memória se enraíza no concreto, no espaço, no gesto, na imagem, no objeto. A história só se liga às continuidades temporais, às evoluções e às relações das coisas. $A$ memória é um absoluto e a história só conhece o relativo. (NORA, 1993: 22)

Ao versar sobre a relação entre memória e História Nora pondera acerca da espontaneidade da memória, vinculada ao presente e com relações diretas com o coletivo e o individual. Já a História é apresentada como sendo produtora das interpretações do passado e em função de seu dever crítico por vezes desautoriza a memória. Nesse sentido, depreendemos que a memória é um conjunto articulado de fatos que tem repercussão tanto nas memórias pessoais quanto nas coletivas, por assumirem significados para os sujeitos e acabam por assumir um papel de vetores. Por outro lado, a História opera em uma esfera que interpreta esses fatos por intermédio de todo um conjunto teórico e metodológico. 
Ao nos confrontarmos com essa perspectiva urge, que o historiador, em seu ofício, é muitas vezes responsável por adentrar profunda e invasivamente no campo das memórias. Desse modo, pode-se compará-lo a um violador que contextualiza, problematiza, confronta e não apenas coleta e reproduz. Desta forma, analisando as audiências e materiais disponibilizados pelas Comissões Nacional e Estadual, questionase: estamos diante de que tipo de produção memorialística? Uma produção de memórias históricas que objetivam enfrentar o presente e o passado ou um conjunto de compilações de fatos e testemunhos que, por mais reveladores que sejam, não mobilizam ações atreladas à realidade dos direitos humanos no presente.

Partindo de uma análise dos objetivos delineados pela CEV-PR no que tangencia a estruturação de uma memória acerca do doloroso processo e das cicatrizes deixadas pela Ditadura Civil Militar no Brasil, observamos que uma das proposições é a da emergência das memórias das pessoas que sofreram algum tipo de violação ou privação de direitos durante o período militar.

Ao pautar-se na noção de "direito à memória", destinado a grupos sociais que tiveram suas experiências sociais e históricas silenciadas, encontramo-nos diante de um projeto político que visa estabelecer ou dar visibilidade a uma nova memória, até então emudecida, assim como a CNV também se pauta por esta preocupação.

Destarte, tanto a comissão nacional como a estadual apresentam objetivos com caráter dicotômico sobre a noção de uma memória e sua relação com a ideia de reconciliação.

O Relatório Final da CNV, já em sua apresentação, afirma que o trabalho desenvolvido "Empenhou-se, assim, em examinar e esclarecer o quadro de graves violações de direitos humanos praticadas entre 1946 e 1988, a fim de efetivar o direito à memória e à verdade histórica e promover a reconciliação nacional" (CNV, 2014: 15).

Nesse sentido, observamos que o documento pontua, com clareza, que a finalidade dos trabalhos desempenhados foi de "esclarecer as graves violações", “efetivar o direito à memória” e "promover a reconciliação". Os levantamentos documentais apresentados e as entrevistas realizadas parecem dar conta de trazer à tona 
várias situações que atentam contra os direitos humanos, dando visibilidade a estes. A noção de memória e reconciliação também está muito presente ao longo de todo o documento e revela um conjunto de tensões de natureza política, econômica e social que devem ser problematizados.

A construção de uma memória acerca das vítimas da ditadura encontra-se atravessada pela noção de verdade, a qual cabe diferentes e, por vezes, contraditórias acepções, de acordo com os interesses dos sujeitos e dos grupos que se analisam, principalmente quando se trabalha com o testemunho. Outro ponto que é revelador deste conjunto de tensões é a ideia de reconciliação, pois como reconciliar vítimas e violadores, sujeitos e instituições, excluídos e beneficiários do regime? Seria somente o trabalho de memória capaz de contribuir com o luto das vítimas? Ou seria apenas uma reconciliação do ponto de vista da política nacional?

Em uma análise ainda inicial, podemos pontuar que nos encontramos diante de uma "dupla responsabilidade" do Estado ao procurar implantar uma Comissão da Verdade: proporcionar o espaço para as vítimas compartilharem suas experiências e, ao mesmo tempo, reconhecer os direitos garantidos dos supostos violadores. Essa dupla responsabilidade tem uma motivação histórica, ligada à trajetória de esquerda do Partido dos Trabalhadores (PT) na luta pela democracia. Por outro lado, vê-se um amparo legalista das forças armadas, pautado nos dispositivos da Lei da Anistia, bem como numa série de situações políticas ligadas aos limites das reparações.

Todavia, é possível observar algumas contradições internas acerca dos documentos finais da CNV e CEV-PR, principalmente no que tangencia a ideia de punição e reparação, bem como da noção de reconciliação. Enquanto o termo reconciliação aparece de modo mais recorrente nas disposições do relatório final da CNV, no relatório da CEV-PR o termo é praticamente abandonado, aparecendo apenas três vezes ao longo de todo documento - um total de 789 páginas -, sendo todas elas em referência a disposições da Comissão Nacional. Porém, é presença muito mais intensa a ideia de “direito à memória” e "justiça”. 
O relatório paranaense traz ainda afirmações mais categóricas acerca do direito à reparação, alegando que "o único acordo possível é o estabelecimento de mecanismos (de justiça) que reparem, responsabilizem e impeçam, de todas as formas, que o futuro repita o passado" (CEV-PR, 2014: 21), delineando um outro campo de pensamento, que mostra uma desconformidade ou, talvez, um descontentamento, com as disposições gerais e orientações dos documentos produzidos em nível nacional. Neste sentido, uma leitura inicial, demonstra discordância entre a ideia de uma reparação apenas no campo simbólico e a construção de uma memória acerca das vítimas. Essa discordância com o modelo delineado na implantação da CNV fica ainda mais evidente na postura mais crítica que alguns trechos do relatório estadual lançam ao Estado brasileiro:

Se a Justiça de Transição exige reparação às vítimas e definição das formas de reparação, ela igualmente exige definição de critérios para a acusação dos perpetradores, como também, das formas de punição, sejam estas através de sanções penais ou políticas. Em relação à primeira exigência, o Estado brasileiro tem respondido favoravelmente. Já em relação à segunda exigência, a decisão do Supremo Tribunal Federal na Arguição de Descumprimento de Preceito Fundamental 153, que julgou constitucional o parágrafo 10, do art. 10 da Lei de Anistia, antecipou um futuro desolador. (CEV-PR, 2014: 23-4)

Assim, duas mentalidades distintas aparecem até o momento. Uma se delineia a partir de um projeto político que opera a noção de que é necessária uma desconstrução do passado e reconstrução da memória objetivando a "reconciliação nacional", enquanto outra parte do princípio que o trabalho de verdade e memória, ao revelar sofrimentos tem um compromisso histórico de questionamento das intransigências e de reparação das vítimas.

Ao visualizar esta dicotomia, lembramo-nos dos apontamentos da pesquisadora Rebecca Saunders, ao problematizar a atuação da Comissão da Verdade e Reconciliação na África do Sul, cuja discussão versa sobre muitos procedimentos adotados, as técnicas observadas, as orientações e ideais a que se prestam, entre outros. Nesse sentido, a autora evidencia o modo pelo qual os testemunhos obtidos na Comissão se tornaram traduções para o sofrimento humano (inteligível e ininteligível), como a linguagem dos 
Direitos Humanos pode acabar tendo finalidades paradoxais: ao mesmo tempo libertadora, mas também podendo ser tirânica (Cf. SAUNDERS, 2008: 53).

Assim, ao analisar o procedimental adotado pela Comissão da Verdade e Reconciliação da África do Sul, a autora citada observa que, muitas vezes, ela foi mais conivente com perpetradores do que com suas vítimas. Isto se dá em função de uma retórica e de um projeto político construído naquele contexto - final do Apartheid, democratização, neoliberalismo, holofotes internacionais etc. -, que objetivavam a reconciliação da nação. Destarte, podemos visualizar que a forma de reabilitação a qual se constitui a partir da CVR operou mais na concretização de formas nacionais de reabilitação (paz social, reconciliação, anistia etc.), do que no desenvolvimento de formas individuais (indenizações, ressarcimentos, processos, prisões etc.). Todo o arcabouço de ações desenvolvidas, embora traga à tona uma série de problemas e abusos de direitos humanos gestados durante o Apartheid, não rompe com as engrenagens sistêmicas da pobreza e da exclusão, ou seja, estão desconectadas da realidade do presente.

Nesse sentido, apesar das divergências diagnosticadas até o momento, visualizase uma ideia comum para ambas as propostas que consiste em operar no campo da memória, promovendo uma reparação simbólica, tirando essas histórias do esquecimento e procurando compor uma memória coletiva fundada na não repetição das graves violações do passado.

No tocante à reparação simbólica, adentramos numa seara que demanda a reflexão acerca dos testemunhos produzidos ao longo das audiências da CEV-PR. No cenário atual lembrar tornou-se uma obrigação, situação fundamental para que se estabeleça uma cultura da memória, para que se traga à luz lembranças que foram silenciadas ao longo do processo histórico. Nesse sentido, François Hartog (2013), historiador francês, desenha um grande ensaio sobre como o tempo é experimentado socialmente, analisando diferentes panoramas históricos a partir de uma multiplicidade de fatores que compõem o tecido social. Movendo-se na fronteira de diferentes práticas historiográficas, tem-se uma reflexão acerca dos meandros do próprio ofício do historiador. Deste modo, o autor irá desenvolver sua principal categoria para análise histórica, os "Regimes de Historicidade", que consistem na percepção analítica da 
Hartog reconhece que a constituição do passado pelo historiador conecta-se com as visões pautadas e articuladas no presente, observando a articulação de diferentes tempos historiográficos, isto é, uma multiplicidade de regimes de historicidade. Para este autor, na sociedade atual, o presente se encontra dilatado, expandido sobre si, inábil para ocupar os vazios entre a experiência e a expectativa. Assim, uma cultura fundada na memória, no patrimônio, nas comemorações, torna-se mais usual, procurando um certo enraizamento, um sentido para suas vivências.

Partindo dessa leitura, podemos entender um pouco a necessidade de se construir uma cultura da memória das vítimas da ditadura, pois o presente, despido de um passado que possa ser tomado como exemplo, sem grandes perspectivas para seu futuro, vê-se na iminência de se reinventar, repensando este passado a partir de si.

É importante dimensionar que muitos pensam que somente um quarto de século após o fim da ditadura se pensou em implantar uma comissão da verdade, porém devemos salientar que no caso brasileiro, em função de suas particularidades históricas, o processo se deu de modo mais moroso e que o ambiente político construído entre 2003 e 2010, durante o primeiro e segundo mandato do presidente Luís Inácio Lula da Silva, engendrou um clima bastante favorável para o amadurecimento e criação de uma Comissão para apurar as graves denúncias contra a ditadura. Uma sobreposição de fatores deve ser levada em conta para que possamos compreender de maneira mais ampla esse processo, como a orientação política de esquerda e de enfrentamento à ditadura de parte da militância petista, as lutas políticas e conquistas dos movimentos de familiares de presos e desaparecidos políticos entre as décadas de 1980, 1990 e 2000, como foi apresentado pela cientista política Glenda Mezarobba (2006: 50) em sua tese de doutorado. A isso se soma o clima de prosperidade econômica e social pós 2003, bem como a ruptura de uma mentalidade que atrelava presos, desaparecidos e opositores ao regime militar como criminosos e o fato de a própria presidenta Dilma Rousseff ter sido militante, presa e torturada no período ditatorial. 
Outrossim, devemos também visualizar que, todo esse clima propício às tensões e disputas por uma memória continuam a existir - vide o embate entre os ministros Paulo Vannuchi (Direitos Humanos) e Nelson Jobim (Defesa), no qual este último chegou a ameaçar entregar a pasta e se demitir por acreditar que o projeto de uma comissão da verdade era "revanchista e provocativo" à honra e memória dos militares ${ }^{3}$ - e embora ocorrido ainda na época da instalação da Comissão, não desapareceram por completo em tempos atuais.

Ainda assim, em meio a um clima de tensões, o historiador Carlos Fico assinala que até há pouco tempo, assuntos relativos ao golpe de 1964 e o regime militar eram foco de poucas pesquisas; eventos sobre o tema eram cancelados, havia poucos debatedores e o públicos era escasso. Todavia, com o distanciamento histórico do fato e a abertura de arquivos, novos documentos, novas leituras entram em cena. Uma das possíveis explicações reside no fato de que antigos estereótipos e até mitos acerca do período vêm sendo superados em função de uma pesquisa histórica séria e comprometida, bem como o "desprendimento político" que também auxilia nesta dinâmica, pois permite que até mesmo visões cristalizadas pela esquerda e pela oposição ao regime possam ser questionadas e revistas. Nas palavras do próprio autor:

Processa-se uma mudança geracional, sendo cada vez mais frequente que pesquisadores do tema não tenham parti pris. Nesse sentido, tem sido destacado o pequeno apreço dos principais atores históricos do período do golpe de 64 pela democracia (inclusive a esquerda); o "deslocamento de sentido", operado sobretudo após a Campanha da Anistia, relativo às esquerdas revolucionárias que foram para a luta armada, outrora apresentadas como integrantes da resistência democrática. (FICO, 2004: 30)

\footnotetext{
${ }^{3}$ As divergências explicitadas entre os ministros são reveladoras das tensões que atingem os grupos envolvidos no processo de montagem da CNV, uma vez que os ministros foram transformados em fiadores de setores com interesses antagônicos. Nesse embate de forças políticas e sociais, o texto final sancionado pontua que "As atividades da Comissão Nacional da Verdade não terão caráter jurisdicional ou persecutório." (BRASIL, 2011). Isto implica dizer que a criação da comissão vem despida do caráter de punição jurídica ou criminal dos envolvidos optando por reparações que se dariam muito mais no campo simbólico do que do direito e da reparação material, tanto que o termo "Justiça" foi retirado e o nome foi apreciado como "Comissão da Verdade". Acerca deste episódio ver: <http://www.estadao.com.br/noticias/geral,jobim-faz-carta-de-demissao-apos-ameaca-de-mudar-a-lei-deanistia,488515>.
} 
Esse novo contexto tracejado entre 2003 e 2010, embora guarde suas contradições, fez-se favorável à rememoração de acontecimentos ligados à ditadura civilmilitar e que, muitas vezes, foram esquecidos ou silenciados. Assim, evocamos a noção de que o distanciamento dos acontecimentos também é importante para que os indivíduos tivessem condições de narrar suas experiências, refletissem criticamente sobre o seu passado e trouxessem à tona aquilo que estava guardado, pois além de um espaço propício para se falar do passado havia ouvidos atentos e dispostos a ouvirem ${ }^{4}$. Igualmente, devemos situar que as narrativas remontam a episódios e acontecimentos relativos aos anos das décadas de 1950, 60, 70 e 80, mas são rememorados e ressignificados a partir de um contexto presente, a partir de experiências do tempo presente.

Variados elementos colaboraram para os depoimentos prestados nas audiências da CEV-PR além dos até então destacados, como o fato de que, para muitos, narrar suas experiências era um prestígio, um momento de se afirmar e, para outros, de tentar dizer o indizível.

\section{Testemunhos em perspectiva}

Dentre as centenas de entrevistas da CEV em todo Paraná, 19 delas foram em Cascavel e trazem testemunhos com o objetivo de "atestar", demonstrar "aquilo que viu" e, o historiador, não pode "ver pelo outro". Deste modo, deparamo-nos com a pretensão de transportar uma realidade sentida em seu caráter subjetivo para uma perspectiva objetiva, o que por si só já traz uma série de complexidades.

Outro ponto é que, embora passadas mais de três décadas, aqueles que sofreram ainda são vítimas e o fato de testemunhar pode ser uma oportunidade de levar à baila memórias e experiências que Ihes permitam "sair da condição de vítima", colocando-se na condição de testemunha, denunciando aqueles que de uma forma ou de

\footnotetext{
${ }^{4}$ A historiadora Carla Conradi faz importante avaliação ao analisar os recentes protestos de 2015 nos quais muitos manifestantes queriam o impeachment da presidente Dilma Rousseff, outros clamavam pela volta pela ditadura, pediam intervenção militar e, até mesmo, alguns defendiam que deveriam ter sido mortos todos (opositores e esquerdistas) em 1964, o que nos leva a indagar se estes mesmos sujeitos que narraram suas histórias e denunciaram violações estariam abertos a compartilhar suas experiências no clima que atualmente se delineia.
} 
outra violaram seu espaço de direitos, possibilitando caminhos para a construção de uma nova identidade "pós catástrofe" (Cf. SELIGMANN-SILVA, 2005: 87-88).

Nessa perspectiva, uma fala que se faz emblemática ao longo dos trabalhos da CEV-PR, em Cascavel, é o testemunho do Sr. Valdetar Antônio Dorneles. Ela é repleta de informações, rica em detalhes, bem estruturada, seguindo uma ordem cronológica dos acontecimentos e manuseando com precisão datas, nomes e fatos, talvez em função da atuação dele na articulação de uma nova memória acerca do período de repressão militar. Todavia, vemos na fala do Sr. Valdetar uma "voz autorizada", alguém capaz de atestar a veracidade de tudo o que ali é relatado, como pontua Eliza Casadei:

É pela vivência direta que se cria a impressão de que as testemunhas estão autorizadas a comentar sobre o assunto e, mais do que isso, tem o seu depoimento acreditado. A presunção de verdade é acionada pela posição que os personagens assumiram na cadeia de eventos passados e, como participantes diretos dos acontecimentos, suas falas funcionam como provas de autenticidade das posições que se querem confirmadas. (CASADEl, 2010: 122)

A fala de Valdetar, que inaugura os trabalhos da Comissão naquele dia, é bastante significativa, sendo que ela se estendeu, contando com o espaço de questionamentos, por aproximados 60 minutos. Em seu depoimento observa-se uma linearidade cronológica, narrando eventos de seu passado no interior do Rio Grande do Sul, o envolvimento de sua família com a política do período, a vinculação aos ideais políticos brizolistas, bem como aspectos de sua trajetória que reivindicam para si um certo protagonismo dos fatos, tecendo-se enquanto voz autorizada a narrar aqueles episódios. Em seus comentários iniciais, quando descreve sua trajetória de vida em que fez "um pouco de tudo", foi "agricultor, operário, eletricista, trabalhei em diversas coisas", trabalhou em usina, foi capataz, serviu ao exército "onde aprendi a lidar com armas" e segue descrevendo que cuidou do irmão enquanto "a mãe carpia terrenos para ganhar o sustento". Pontua ainda que, em 1959, quando o Rio Grande do Sul era governado por Brizola e com a abertura de milhares de escolas, ele se apresentou para ser educador e prestou o concurso e, mesmo há muito tempo sem estudar, foi aprovado 
Valdetar, de modo fluído, atrela sua vida a momentos importantes da história do Brasil, como em 1961 - campanha pela legalidade. Demonstra admiração por Leonel Brizola. Coloca seu pai como amigo de Prestes. Por conta do pai assumir a liderança do comitê da legalidade a família ficou marcada. A testemunha se coloca como secretário do movimento e em abril de 1964 teve sua casa invadida por militares, enquanto a família estava no futebol, levando todas as armas, até mesmo facas de cozinha e a partir daí intitulando a família dele como "os comunistas" - iniciando então a perseguição e a rotulação pela comunidade.

Delineada uma breve trajetória de vida, o ápice da fala do Sr. Valdetar é referente às prisões e torturas sofridas ao longo da resistência ao regime, o que é reforçado na centralidade das questões levantadas pela mesa. Um dos principais pontos foi a prisão de 18 guerrilheiros no Sudoeste do estado e seu deslocamento até Foz do Iguaçu:

Bom, fomos conduzidos dali até Foz do Iguaçu, e quando chegamos em Foz do Iguaçu, tinha uma fileira enorme de soldados, e desamarraram nós do caminhão e nós levava pontapés e socos, até chegar dentro da prisão, lá na prisão, em seguida, nos amarraram pelas mãos e seguraram dentro da grade, ai a bordoada pegou. Três dias, não tinha água, não tinha comida, nem nada.[...].

Eu sofri muito dentro da prisão, no meu corpo depois eu posso mostrar pra vocês as marcas, as queimadura, cabeça quebrada, nariz torto, é, os sinais das corda faz cinquenta anos e ainda se nós olhar aqui bem, vamos achar sinal de corda nos meus braços, nas minhas perna, aqui nos meus dedos foi feito as alianças, que só a sepultura vai apagar isso aqui. (DORNELES, Valdetar. Audiência CEV-PR)

A partir do deslocamento do testemunho para a experiência abre-se um flanco para o trabalho de memória em um nível mais próximo ao literário. O testemunho quer resgatar o que há de mais terrível no real, mesmo que para isso se utilize de estruturas ou suportes apreendidos ao longo das vivências cotidianas, como forma de criar coerência, uma vez que a linguagem é produtora de sentidos. 
A violência descrita pelo militante expressa um pouco do que foi a violação dos direitos humanos durante o regime militar brasileiro. Demonstra objetivamente como se faz necessário trazer à tona os testemunhos pós-tragédias e publicizar os acontecimentos de modo a assegurar sua não repetição em circunstâncias futuras. Todavia, apenas relatar as violências sofridas pode não ser o suficiente para garantir uma perlaboração mais ampla, como bem pontua Márcio Seligmann-Silva: "a base do testemunho consiste em uma ambiguidade: por um lado, a necessidade de narrar o que foi vivido, e por outro, a percepção de que a linguagem é insuficiente para dar conta do que ocorreu" (2003: 46).

Assim, ao analisar a totalidade do testemunho do Sr. Valdetar, o viés metodológico volta-se a uma especificidade que precisa ser contextualizada: o militante expõe, tanto no passado como no presente, enquanto voz autorizada para falar sobre o Movimento no Estado, personificando, ainda nos dias de hoje, a luta pela anistia a partir de sua militância política.

Segundo Alistair Thomson nossas memórias são compostas como forma de atribuir sentido ao nosso passado e presente. As lembranças dos fatos vivenciados são modificadas à medida que nossa identidade pessoal vai se alterando, demonstrando que identidade e memória se constituem numa relação de grande proximidade e dialogia, de modo que compomos um passado com o qual possamos conviver (Thomson, 1997: 58).

Alguns testemunhos coletados na audiência não foram pronunciados pelas vítimas diretas da Ditadura Militar, mas por seus familiares, em função de impossibilidades ligadas à saúde, à idade já avançada das vítimas, ou mesmo falecimento em alguns casos. Nesse sentido, Clarissa Mertz fala na audiência em lugar de seu pai, já falecido, e seu relato se desdobra principalmente em descrever a experiência vivida em meio a uma família que foi vitimada pela ditadura. A narrativa se pauta nas sensações experimentadas, no preconceito sofrido, nas lacunas deixadas e nos impactos da violência simbólica que ter um familiar perseguido e rotulado como guerrilheiro e subversivo pode trazer: 
E a situação de repúdio e hostilidade da sociedade era gigantesca, assim como havia companheiros, pessoas valorosas que auxiliavam economicamente a não passar fome... todas as necessidades materiais que foram passadas, a maioria da população via e ainda vê com maus olhos aquela história. Os jornais locais tratavam de aniquilar o sentimento das pessoas, dizendo que o cidadão que então era um bom profissional odontológico, um excelente vereador, passara a ser subversivo, trair a sua pátria e a sua família.. estampado na capa do jornal. Então as dificuldades foram inúmeras, e as sequelas também, até hoje. (MERTZ, Clarissa. Audiência CEV-PR)

A voz embargada e a emoção de Clarissa são perceptíveis em seu testemunho. Falar de si pode ser uma experiência libertadora, todavia é importante termos a ciência de que as lembranças não abandonam a memória tão facilmente e que o trabalho de perlaboração é ainda mais intenso e mais amplo do que a exposição de sua experiência familiar junto à Comissão.

O tom da fala, as cenas descritas, a imposição da voz emocionada, dão a entender que Clarissa quer falar, que seu passado e seu corpo querem falar e expor sentimentos que ainda estão recolhidos.

Eu por fim, eu quero dizer, que a dor, o trauma, de toda essa experiência familiar, dessa história, de luta e de perdas, é gigantesca, enorme. E é a mesma história vivida pela grande maioria das famílias desses nobres homens que estavam à frente do movimento. Mas assim como havia a minha mãe, havia a mãe do seu Valdetar fazendo comida para um pelotão, haviam outras inúmeras valorosas mulheres, valorosas filhas, valorosas mães, que foram sim braço forte desses acontecimentos e eu tenho muito orgulho, tenho muita dor, tenho muita revolta... Mas nada se compara ao orgulho de ser filha, não de um covarde torturador, mas sim de um homem que lutou pelos direitos de cidadania e lutou contra o regime que acometeu todas essas barbáries. (MERTZ, Clarissa. Audiência (EV-PR)

O relato de Clarissa é verdadeiro. É parte de sua história. É parte da composição de sua vida. Todavia, analiticamente não podemos perder de vistas que estas memórias são tecidas e mantidas atreladas àquilo que Welzer, Moller e Tschuggnall (2012), a partir das noções de Halbwachs classificaram como sendo "o caráter moral de nossos pais". Especificamente no caso de Clarissa, observamos que ela testemunha em lugar de seu pai, destacando a sua experiência em uma família atingida pela violência e desestruturada 
pela Ditadura, mas que sua fala também é mediada pelo sentimento construído em relação ao pai. Assim, juntamente com essa "moral” acerca do personagem principal, seu pai, podemos delinear o que os autores classificam como um "processo de heroicização", fortalecendo relações de lealdade entre a própria família, mesmo que se desconsiderem situações contraditórias ou se preencham lacunas com interpretações pessoais dos fatos.

Não estamos dizendo aqui que o testemunho de Clarissa é inverídico ou construído de modo distorcido, pelo contrário: seu testemunho é produtor de sentidos para sua vida e orientador de comportamentos.

No dia seguinte aos depoimentos de membros da Guerrilha de 3 Passos, de integrantes dos Grupos dos Onze e agricultores atingidos pela violência do Estado durante o governo militar, dia 21 de março de 2014, foram ouvidos indígenas que narraram as experiências de suas comunidades com a ditadura. Os testemunhos também são um rico repertório para análise dos trabalhos da CNV. A fala de Silvania Benitez, indígena Guarani, é repleta de elementos que devem ser problematizados:

Eu lembro pouco né, naquela época eu era pequena ainda né. Mas eu lembro que na época que deram as enchentes a gente saiu de lá, meu pai ficou desesperado, minha mãe também, porque a gente perdeu tudo que tinha né? E fomos pro porto de Guaíra daí, ficamos lá, embaixo de lona, e meu pai levou a gente de bote. E deu pra levar pouca coisa, era muito e não deu pra levar tudo né. As coisas foram deixadas, e a gente perdeu bastante. A única coisa que deu pra levar foi nós mesmos e umas peças de roupa que a gente tinha! E eu me lembro que foi bem triste, porque na verdade a gente não sabia pra onde ir né, e toda aquela água entrando e a gente sem ter pra onde ir! E nós éramos todos pequenos né... (BENITEZ, Silvania. Audiência CEV-PR)

Quando do período da inundação da área onde se localizada a aldeia, Silvania ainda era criança. Suas lembranças podem não ser as mais precisas, mas se estruturam a partir, também, de relatos compartilhados pelos pais e demais integrantes da tribo, fixando imagens em sua memória e construindo elementos que norteiam suas percepções acerca do vivido.

Não se questiona aqui a gravidade da violência de uma expulsão de suas terras, a perda de vínculos afetivos que desenvolvem no lugar onde se constroem vivências 
François Hartog pondera que o estatuto de vítima garante o suporte necessário à autoridade e nutre uma espécie de "temor reverente" que, muitas vezes, promove uma identificação perigosa entre verdade e autenticidade, "no momento em que deveria ser mantida a separação entre a veracidade e a confiabilidade, por um lado, e, por outro, a verdade e a prova" (HARTOG, 2006: 227). Em direção muito semelhante, Beatriz Sarlo acena para os modos pelos quais o ambiente destas Comissões da Verdade constroem uma atmosfera propícia para a construção de narrativas vitimizadoras, nas quais os sujeitos produzem um discurso capaz de se adequar àquilo que pressupõem querer ouvir os entrevistadores, ou seja, uma condição de vítimas ou mártires.

Não podemos esquecer que a entrevista não é algo natural, mas algo provocado pelo historiador, no caso específico, por uma comissão que se presta a ouvir os tipos de violações que ocorreram no passado, de modo a tornar a entrevista ainda mais complexa. Nesse sentido, a fala de Silvania Benitez, bem como de outros indígenas, não é tão espontâneas quanto pode parecer. A resposta construída se dá num contexto no qual, momentos antes, a antropóloga Maria Lúcia Brant de Carvalho havia indagado: “E nunca ninguém indenizou o que vocês perderam?". As construções narrativas podem simplesmente ser analisadas quando retiradas do contexto mais amplo da entrevista.

Diante do nosso entendimento, a pergunta da entrevistadora abre margem para um ponto fundamental: a aproximação da condição de vítima que se invoca com uma das principais reivindicações dos povos indígenas - a terra. Ao abordar sobre a não indenização aos povos retirados da região de Guaíra, envereda-se para um campo no qual a não reparação adequada destes indivíduos e a realocação forçada é um dos principais estruturadores de suas vivências desde a expulsão.

Ademais, os relatos coletados juntos aos indígenas na audiência realizada no dia 21 de março de 2014, além das solenidades próprias à abertura do evento, contou com uma fala inicial da antropóloga contextualizando a questão dos povos indígenas no 
Estado do Paraná. A fala de Maria Lúcia Brant de Carvalho é riquíssima em detalhes e esclarecimentos acerca da problemática das terras indígenas e das violações sofridas por essas populações, chegando a mencionar o quão delicado e perigoso se torna adentrar nesse debate em tempos atuais. Outrossim, devemos observar que os indígenas geralmente são uma população que, até mesmo como um mecanismo de defesa, costumam falar aquilo que o interlocutor quer ouvir ou, até mesmo, costumar dar desinformações propositalmente para o inquiridor, como apontam alguns estudos. Nesse sentido, ao longo das narrativas, percebemos discretamente uma tendência a tentar reproduzir falas com conteúdo político e questões ligadas à expropriação. Não estamos aqui sugerindo uma interferência grosseira ou uma influência que conduziu as narrativas indígenas, pois a literatura histórica acerca do assunto e o próprio trabalho da antropóloga servem de baliza para constatar a violência e o constante avanço da agricultura sobre as áreas indígenas, mas que esta realidade ligada às terras deles se torna o mote principal a ser explorado nas entrevistas.

Para Beatriz Sarlo, o testemunho tem por base a experiência - sem ela não existe o testemunho. Não obstante, a experiência somente existe com a narração, pois

a linguagem liberta o aspecto mudo da experiência, redime-a de seu imediatismo ou de seu esquecimento e a transforma no comunicável, isto é, no comum. A narração inscreve a experiência numa temporalidade que não é a de seu acontecer (ameaçado desde seu próprio começo pela passagem do tempo e pelo irrepetível), mas a de sua lembrança. A narração também funda uma temporalidade, que a cada repetição e a cada variante torna a se atualizar. (SARLO, 2007: p. 24-5)

Partindo dessas considerações, devemos assinalar que a relação entre testemunho e experiência é bastante complexa e possibilita uma fluidez, bem como uma perenidade em sua composição, não podendo estes serem tomados pelo historiador como algo fixo e imutável, uma vez que ao narrar o passado é o presente que delineia as formas desse passado, a partir das experiências pelas quais se orienta o narrador. Mas também a experiência é objeto do testemunho que a cria e recria através de enredamentos muitas vezes contraditórios. Nessa perspectiva, assinalamos ainda uma dificuldade ou impossibilidade de separação entre experiência, memória e narrativa, pois 
inexiste uma unidade do eu, e a subjetividade do relato se encontra perdida em múltiplas temporalidades.

A memória, como postula Halbwachs (2006), suporta a tensão e o anacronismo, trazendo o passado recordado para muito perto da realidade em que se vive. Aqueles que lembram não estão isentos das lutas e conflitos na contemporaneidade, podendo imputar ao passado as impressões que são próprias do presente. Sob esta seara, as constantes menções ao passado se dão no sentido de delinear as privações e problemas sofridos após a expulsão e, em nenhum momento das audiências, em considerar como eram a vivências anteriores a isso, como, por exemplo, na fala de Rosalina, ao falar sobre de onde saíram:

É a ilha... São Pedro! Ilha São Pedro! E nós morávamos lá, e depois viemos pra cá, nesse lugar que a gente tá agora, e até hoje não encontramos todo mundo, família até hoje não apareceram. Minha filha, minha cunhada morreu. E as crianças quando chegaram também, pegaram sarampo, pegaram tudo, só por Deus que não morreram de outras maneiras. E nós perdemos tudo que a gente tinha! Perdemos cachorro, perdemos gatos, e as crianças todas pequenininhas ainda! Lá a gente ainda plantava, tinha mandioca, tinha milho. Mas nessa terra não dá nada! (BENITEZ, Rosalina. Audiência CEV-PR)

Não nos encontramos ainda, em um momento que nos permita visualizar com maior nitidez se a análise deste silenciamento sobre o passado na llha é uma especulação correta, porém configura-se em mais um questionamento ao qual devemos nos debruçar em outro momento.

Todavia, podemos observar que a narrativa acima é estruturada dando destaque aos episódios trágicos que se sucederam após a expulsão da terra. Uma das interpretações possíveis da fala de Rosalina é o modo como uma narrativa de acontecimentos passados se encontra envolta em elementos que trazem consigo certos graus de comoção, como forma de evocar um status de autenticidade por intermédio de uma perspectiva emocional tal qual a separação e perda de membros da família, as doenças das crianças, a insuficiência e infertilidade da terra. 
Sobre aquela pergunta de antes, eu achei que fosse interessante de colocar como a gente se sente hoje né. Naquela época que nós morávamos lá, a gente tinha mais família, e eu lembro que nós éramos todos pequenos e meu pai fazia as danças né, eles tinham a cultura deles. E daí depois da enchente, cada um foi pra um canto e a gente veio pra Castro, não teve mais isso sabe? E antes a gente até tinha um pouco de afinidade de entender as coisas, entender o que eles falavam, mas agora... A gente foi crescendo no meio dos brancos e foi perdendo essa cultura! Então eu acho que o pior de tudo isso foi a gente perder a nossa cultura, porque além de perder tudo o que nós perdemos, nós ainda perdemos nossa cultura! (BENITEZ, Silvania. Audiência CEV-PR)

A fala de Silvania traz um dos raros momentos em que o passado anterior à expulsão é relembrado: “naquela época que morávamos lá, a gente tinha mais família”. A rememoração dessa anterioridade faz parte da construção do sentido que a entrevista quer dar a sua narrativa, apresentando o impacto negativo de todo processo de realocação para os membros da aldeia. Outro ponto destacado é a transformação cultural que se deu a partir do contato e incorporação de costumes externos aos da sua comunidade.

A descrição da entrevistada apresenta-se envolta numa gama de subjetividades que demonstram como a expropriação da tribo é portadora de uma violência material, mas também simbólica capaz de causar o desenraizamento e a perda de elementos identitários do grupo. Como a identidade é um dos condicionantes da relação indivíduocoletivo, resta claro ser através dela que o indivíduo desenvolve sentimentos de pertencimento, sentindo-se parte do grupo. No entanto, perder traços de sua cultura implica, também, perder parte daquilo que se é no mundo, vivendo uma situação de estranhamento, de perda de referências e com impactos sociais e psicológicos de grande proporção.

Outrossim, devemos observar que, como assinala James C. Scott (2013), as práticas de resistências e lutas advêm também de um determinado modo de vida. Nesse sentido, a luta não se dá apenas por motivos econômicos, mas por valores, pertencimento, ambiência, preservação de saberes etc. Os comportamentos assumem sentido a partir do momento em que os sujeitos lhe atribuem significados. Ou seja, o autor pondera que o Discurso Oculto não serve apenas para elucidar ou explicar a 
conduta dos indivíduos, mas contribui em sua constituição e é aí que se observa a construção e o papel do "infrapolítico", a construção de uma consciência dos direitos dos indivíduos, fomentando práticas que, se assumidas publicamente, colocariam em perigo os sujeitos. Em outras palavras, os indivíduos constroem suas interpretações acerca do que é legal e do que é moral, sendo possível estabelecer um paralelo com as discussões de E.P. Thompson e "economia moral camponesa" no tocante ao direito consuetudinário, ligado à tradição, ao costume, à memória, atuando na construção de sentimentos, práticas e sentidos, que irão impregnar a consciência e as ações cotidianas dos indivíduos (THOMPSON, 1998: 259).

Os apontamentos até aqui realizados partem de uma leitura inicial acerca do objeto em questão, centrando-se em uma interpretação parcial dos relatórios das Comissões da Verdade (Estadual e Nacional), bem como de alguns depoimentos coletados durante as audiências públicas realizadas em Cascavel - PR. Até o momento, é possível pensar algumas supostas tensões e ambiguidades na estruturação e nos trabalhos das comissões, bem como a importância de problematizar a hegemonia moral que se confere ao testemunho.

Destacamos que, embora construídos dentro de uma certa perspectiva estética e retórica, as narrativas não são mais ou menos verdadeiras, são, fundamentalmente, a expressão de quem tem algo a dizer sobre aquelas situações. Diante disso, faz-se necessário pensar a abordagem que compreenda amplamente a relação entre memória e direitos humanos, garantido aos mesmos uma vitalidade política, pois, como aponta Andreas Huyssen existe um risco do discurso da memória ao procurar uma legitimação para o presente voltando seu olhar para o passado, porém sem pensar no futuro. Esse discurso da memória deve estar em consonância com o discurso dos direitos humanos olhando também para o futuro. Em direção oposta, o discurso liberal tipificado tende a pensar os direitos humanos de forma individualizada, desconsiderando as múltiplas histórias e culturas locais, sobrepondo valores ocidentais para realidades que se estruturam de modo completamente diferente. Assim, o discurso da memória deve acenar para um amplo entendimento das particularidades históricas que o discurso dos direitos humanos individuais costuma deixar em segundo plano (Cf. HUYSSEN, 2014). 


\section{A memória em seu processo de composição}

O Sr. Waldemar Torres Rosin, agricultor, residente na linha Pavão, zona rural no município de Capanema, Sudoeste do Paraná, que juntamente com os irmãos participou do chamado Grupo dos Onze ${ }^{5}$, foi uma das pessoas ouvidas na audiência da CEV-PR em Cascavel. Por uma série de circunstâncias seu depoimento é bastante breve, tendo duração de menos de 3 minutos, cercado de nervosismo, entre outros motivos por falar para um auditório cheio e para membros de uma comissão que assumem o papel de autoridades sobre o tema, bem como pela própria condição de agricultor, homem simples que passou praticamente toda sua vida no trabalho no campo. Em essência, o depoimento traz o breve relato da ida de policiais até a casa onde morava com a família à procura de armas e agindo com alguns excessos de força, relatados deste modo pelo depoente:

aquele dia que eles bateram lá em casa, lá no meu irmão, atiraram bastante, não atingiram em nenhum dos homem, e atingiram uma vaca do vizinho lá em cima. Bem no fim a vaca morreu também. E daí chegaram lá em casa, começaram pedir do armamento e tudo e foi, e foi, e foi, e a mãe deixou eles entrar em tudo, reviraram colchão, quarto por quarto, e isso e aquilo, pedindo do armamento, mas a gente não tinha! Que armamento vai ter né? E daí passaram dali, passaram pra debaixo da casa, e daí tinha uma tuia de feijão lá, eles abriram a tuia de feijão... pedindo do armamento... derramaram tudo lá, não tinha nada. Daí eu tava lá em baixo tratando os porco, vieram e pediram de novo: 'onde tá o armamento?' digo, mas armamento não tem. Daí chegou um policial e me botou o fuzil no peito, aí fiquei quieto, saí, pediu de novo, de novo, revistaram minha casa tudo e depois, mais tarde, outro tempo depois, teve uma missa lá na localidade, daí o padre chamou a família Rosin de comunista. Isso foi o que nós, doeu pra nós. E nós semo em onze irmão, irmã, nenhum não trocou de religião até hoje. É isso aí. (ROSIN, 2016: $\mathrm{A} / \mathrm{A})$

\footnotetext{
${ }^{5}$ Os chamados Grupos de Onze Companheiros, simplificadamente, Grupos dos Onze ou Gr-11, e também conhecidos como Comandos Nacionalistas foram concebidos por Brizola no fim de 1963. Tomando por base a formação de um time de futebol, imagem de fácil assimilação e apelo popular, Brizola pregava a organização de pequenas células - cada uma composta de onze cidadãos, em todo o território nacional - que poderiam ser mobilizadas sob seu comando. Era um grupo de esquerda, porém não socialista, era nacionalista e apoiava abertamente as políticas de base de Jango, dentro do contexto de radicalização política do período histórico. (cf. Wikipédia)
} 
Na sequência, Aluizio Palmar, membro da comissão, pontua que passou um tempo em Capanema, em busca de companheiros desaparecidos e que ficou sabendo que o Sr. Waldemar havia sido muito torturado, e incisivamente pergunta que tipo de tortura sofreu, onde e se o olho de vidro que ele possui era fruto da violência sofrida. De modo breve o depoente assim se posiciona:

Não. Esse eu tinha mais ou menos 26 anos quando eu perdi.

Palmar: O senhor chegou a ser preso e foi torturado onde?.

Sr. Waldemar: Não, não, não.

Palmar: Você foi torturado?

Sr. Waldemar: Só aquela uma, né.

Palmar: qual?

Sr. Waldemar: Aquela que ele bateram, né.

Ivete Caribé: Quando o senhor menciona uma, é, o senhor chegou a ser preso uma vez, ou mesmo não tendo sido preso, foi torturado, ameaçado, o que aconteceu?

Sr. Waldemar: Não, não... eu não fui preso, né, mas os meus irmãos foram, porque eu fiquei com a mãe, né, daí a mãe ficava sozinha.

Ivete Caribé: Sim, e o senhor foi ameaçado pelo exército, pela polícia?

Sr. Waldemar: Não, foi só aquele policial que eu tava dando água pros porco, né.

Ivete Caribé: Tá certo! Muito bem. (Audiência CEV-PR)

Diante do depoimento prestado e das questões colocadas pelos membros da comissão, até mesmo de modo insistente, tem-se uma impressão de que estes procuram o relato da violência sofrida em sua forma material, isto é, a tortura, a violência física, dando pouca atenção ao sujeito e suas experiências. Interessante mencionar que nenhum trecho do depoimento do Sr. Waldemar aparece nos relatórios da CNV ou CEV-PR, talvez por não trazer o tipo de informação que a Comissão buscava.

O Sr. Waldemar foi o primeiro depoente da audiência pública de Cascavel com quem conseguimos contato. Embora tendo em mãos seu endereço e telefone, optamos por procurar um mediador que já tivesse amizade com ele, como forma de construir um ambiente de maior segurança para a entrevista futura. Através de uma aluna, cujo pai, o Sr. Feltrin, era amigo do Sr. Waldemar, iniciei os contatos, indo os três para uma primeira conversa, num domingo à tarde, no sítio da família Rosin, na linha Pavão, interior de Capanema. Naquela tarde fomos apresentados, conheci a esposa do Sr. Waldemar, a 
Realizei uma segunda visita, em uma segunda-feira após meu expediente de trabalho, quando mais uma vez conversamos sobre diferentes assuntos enquanto tomávamos chimarrão na área externa da casa. Estas visitas prévias e a intermediação feita pelo Sr. Feltrin foram fundamentais para uma aproximação maior com o entrevistado, fato este que, embora a timidez perante o gravador, deixou o Sr. Waldemar bem mais à vontade durante a entrevista realizada no dia 26 de março de 2016.

Sr. Waldemar encontrava-se mais solto por estar em sua casa, ao lado de sua esposa e, assim, nosso diálogo ocorreu de modo mais fluído e intenso, o que se observa na segurança e na entonação de voz que ele empregava. Partindo das noções e compromissos éticos pontuados por Alessandro Portelli (1997: 13-33), procurei me colocar na condição de quem estava "tentando aprender um pouquinho", procurando me despir da posição de pesquisador e professor, reconhecendo e transferindo para Waldemar o empoderamento de quem era o detentor de um conhecimento de que eu precisava.

Com a transcrição da entrevista em mãos, a condição de pesquisador é a que deve prevalecer. Assim, ao leiturizar a mesma, percebemos o modo como os entrevistados são suficientemente perspicazes para discernir o que o entrevistador quer, quais suas intenções entre outros. Iniciamos nossa entrevista pedindo para o Sr. Waldemar narrar sua trajetória de vida, suas origens, infância, trabalho e afins, sendo assim respondida:

Tudo bem. Eu vim de Criciumal, com... 12 anos, cheguemos aqui e até agora tamo aí ainda. E aquela de 64 (sessenta e quatro), dai nós tava aqui, morava lá em baixo e deu tiroteio tudo aquela ali, foi indo foi indo escaparam, pegaram só um e... daí o Antônio escapou, ficou dentro do riozinho, da valeta ali, e o Lídio ficou ali em cima dum pé de banana lá, e nós tava ai né. $\mathrm{O}$ meu irmão lecionava aqui, tinha a escola aqui aquela vez, tava cheio de aluno, era umas nove e meia dez horas quando bateram aí a polícia e daí foi, foi retiraram e pegaram o Antônio, daí vieram revistar a casa ali em baixo, tava só eu e a mãe ali né, e aquela época era colchão de palha, não sei se o senhor lembra isso e aquilo né, colchão de palha, daí eles queriam saber o armamento né... foram revirando pra cá foram revirando lá né, mas não tinha nada, a única coisa que tem é essa espingarda que tá aí hoje (risos) tinha só dois 
cartuchinhos carregados (risos) de passarinho ainda. Daí não acharam armamento, foi e foi aí foram em baixo do porão, tinha uma tuia de feijão... "é aqui que tá o armamento" pegaram e abriram, derramaram o feijão no chão... feijão do manguá, batido a pau naquela época né, 64, não tinha arma, não tinha nada né, batia pau, não tinha armamento, não tinha nada. Aí me judiaram bastante lá em baixo no chiqueiro dos porco, diziam que eu sabia do armamento, sabia e sabia que o armamento tava aqui, com duas lata d'água, e foi isso. (ROSIN, 2016: A/A)

O entrevistado sabia que meu interesse, em função de minha pesquisa, se voltava para seu depoimento prestado na CEV-PR, assim, logo de início conduz sua fala para o acontecimento. De modo bem mais fluído e à vontade, percebemos uma reprodução da ideia narrada na audiência, no ano de 2014, mas com uma pulsação de sentidos e detalhes bem maiores. Sr. Waldemar acenava e apontava para os lugares onde ocorreu o tiroteio, onde era a escola, onde se esconderam, onde era o chiqueiro, os detalhes da moradia como o colchão de palha entre outros, detalhes narrados acompanhados de sorrisos e expressões que denotavam uma maior segurança do entrevistado.

Não podemos afirmar se era apenas a percepção de meus interesses ou se havia uma necessidade de falar sobre o assunto, de narrar o passado, de se fazer ouvido. Todavia, podemos perceber o movimento que Alistair Thomson (1997: 56) classificou como "composição das memórias", isto é, nossas memórias são compostas na relação entre passado e presente, entre memória individual e coletiva. Nossas reminiscências são compostas de modo a dar sentido à nossa vida, no passado e no presente, utilizando linguagens e significados conhecidos de nossa cultura.

Nesse sentido, o depoimento na CEV-PR se faz presente ao longo de sua entrevista, sendo um elemento importante na construção de sua identidade, não sabemos se era isso antes, mas faz parte da atuação do Sr. Waldemar durante a e entrevista, bem como do processo de construção e composição da sua memória. Destarte, podemos perceber como se tece uma memória da memória, e não do fato em si, isto é, da última vez em que ele se lembrou do fato. Para Alistair Thomson, memória e identidade se encontram em uma relação de grande proximidade: 
Nossas reminiscências também variam dependendo das alterações sofridas por nossa identidade pessoal, o que me leva a um segundo sentido, mais psicológico, da composição: a necessidade de compor um passado com o qual possamos conviver. Esse sentido supõe uma relação dialética entre memória e identidade. (THOMSON, 1997: 57)

Embora na audiência não tenha mencionado com clareza o tipo de agressão sofrida, na entrevista essa memória é composta de maneira mais organizada, dizendo que "Aí me judiaram bastante lá em baixo no chiqueiro dos porco, diziam que eu sabia do armamento". Ao falar que "judiaram bastante" as memórias de Sr. Waldemar já estão sistematizadas com maior clareza e a partir de sua experiência na Comissão da Verdade. A reivindicação e a exposição da violência sofrida já ocupam um espaço na narrativa do agricultor que relata com maior perceptividade o acontecimento: "Meteram o fuzil no peito, me derrubaram e depois me deram uns coices ainda" (ROSIN, 2016: A/A).

Nesse sentido, a própria entrevista faz parte desse processo constante de composição das memórias. O Sr. Waldemar reagiu às minhas perguntas de modo mais tranquilo e inteligível, até mesmo se posicionando quanto ao modo como o ocorrido, estando este re-significado e presente em suas lembranças: “Claro que marca né... quando que o senhor sai ferido e vai esquecer? Nunca mais na vida... nunca mais esquece. Essa mancha fica pra sempre" (Idem), me levando a compreender que a composição das experiências nunca se finda, é constantemente relembrada e retrabalhada.

Na esteira desse entendimento A. Thomson pontua que

As imagens e linguagens disponíveis usadas pelo público nunca se encaixam perfeitamente às experiências pessoais e há sempre uma tensão que pode ser manifestada através de um desconforto latente, da comparação ou da avaliação. Portanto, os relatos coletivos que usamos para narrar e relembrar experiências não necessariamente apagam experiências que não fazem sentido para a coletividade. Incoerentes, desestruturadas e, na verdade, 'não-lembradas', essas experiências podem permanecer na memória e se manifestar em outras épocas e lugares - sustentadas talvez por relatos alternativos - ou através de imagens menos consistentes. Experiências novas ampliam constantemente as imagens antigas e no final exigem e geram novas formas de compreensão. A memória 'gira em torno da relação passadopresente, e envolve um processo contínuo de reconstrução e transformação das experiências relembradas', em função das mudanças nos relatos públicos sobre o passado. Que memórias escolhemos para recordar e relatar (e, portanto, relembrar), e como damos sentido a elas são coisas que mudam com o passar do tempo. (THOMSON, 1997: 56-57) 
Outro elemento importante a ser observado na fala do agricultor é a dimensão da violência simbólica em torno da sua memória e identidade. O episódio descrito ao final do depoimento na audiência da CEV-PR traz o posicionamento do padre da comunidade dando o rótulo de "comunista” à família Rosin: "mais tarde, outro tempo depois, teve uma missa lá na localidade, daí o padre chamou a família Rosin de comunista. Isso foi o que nós, doeu pra nós. E nós semo em onze irmão, irmã, nenhum não trocou de religião até hoje. É isso aí" (ROSIN, Waldemar. A/A).

O julgamento da comunidade e a rotulação é um tipo de violência simbólica, mas nem por isso ela é menos real ou menos violenta que outras formas de violência. Podemos até mesmo arriscar dizer que na ocasião da audiência pública, a fala do Sr. Waldemar demonstrava mais inquietação com essa situação do que com a coronhada que Ihe fora dada pelo policial na altura do peito.

Em nossa entrevista, retornei a este assunto perguntando como havia sido o episódio, que foi assim descrito:

Isso aconteceu até aqui, e o padre de Capanema veio rezar uma missa aqui, na comunidade aqui e taxou nós de comunista. E depois que o Antônio voltou, ele tinha um gadinho ai, dai ele doou uma novilha pra festa da matriz, sempre em Maio né, dai o padre "ah, mas foi engano" e isso e aquilo "não é família comunista", uma novilha pagou daí.

Marcelo: E como vocês se sentiam sendo tratados, taxados como comunistas?

Valdemar: Pois é, mas o que vai fazer? O pessoal daqui não, mas os outros falavam... esses aqui sabia que nós não era... íamos na igreja todos os domingos né, era difícil um domingo que não ia. Depois não fomos mais. (ROSIN, 2016: A/A)

Observamos que a participação no Grupo dos Onze, a troca de tiros com a polícia, o episódio de violência ocorrido em sua propriedade, para além da coação física, atua em seu caráter simbólico, na forma de danos morais e psicológicos. Tal situação pode ser potencializado pelo fato de envolver o padre e igreja local. Nesse sentido devemos analisar o papel desempenhando pela religião, principalmente em comunidades agrárias, como um elemento que garanta uma coesão entre o grupo social. 
Para Durkheim, uma das principais características da religião é sua capacidade de unir um determinado grupo social a partir de um sistema de crenças comuns. Já o sociólogo e teólogo Peter Berger pontua que o "nomos estabelecido é entendido como um escudo contra o terror" (BERGER, 1985: 35), tecendo uma relação entre o indivíduo e a sociedade, acenando para o fato de que a religião oferece ao indivíduo uma maneira de diferir o mundo do "pesadelo da anomia" e conservar-se seguro.

O episódio narrado demonstra como os reflexos da ação policial e do posicionamento do padre local mergulham a família temporariamente numa situação anômica, sendo reparado somente após um dos irmãos, Antônio, doar um novilho para a festa da Igreja e o padre reparar a situação.

Outro ponto significativo acerca dessa questão é quando interpelado sobre o que significava ser comunista, em meio a risos o entrevistado assim se coloca: "Comunista, nem sei o que é".

Diante dessas reflexões sobre os relatos do Sr. Waldemar, e pensando a proposição e as finalidades da CNV em garantir o direito à memória, a dúvida de como estas memórias foram e serão inseridas em uma proposta mais ampla se faz presente. Outro questionamento é que tipo de restituição, depoentes como o Sr. Waldemar e tantos outros têm em relação ao testemunho prestado, como esse trabalho se volta para ele? Será possível pensar que o depoimento prestado permitiu a ele um processo de individuação, subjetivação ou, até mesmo, perlaboração?

Ainda na esfera dos questionamentos, pergunta-se sobre o desejo de reparação material que aparece na entrevista concedida pelo agricultor e que parece ter sido proposto pelos membros da CEV-PR que o procuraram:

Ah, o Elias veio aqui né, ele mais um, não sei qual era o outro me entrevistaram aqui e aí comunicaram pra ir lá, daí eu só falei se o rapaz ia e junto e se eles iriam vir me pegar aqui, daí eles vieram me pegar aqui e levaram, aí meu irmão tava junto lá em Cascavel [...] Mas olha, ficou certo pra eles trazer né, tem até os papel aí tudo, mas até hoje não apareceu.

Mas quem deixou o papel?

Valdemar: Lá da Comissão da Verdade.

É? Eles falaram em reparação, em ressarcimento?

Valdemar: Sim, em seis meses era pra receber, e até agora... (ROSIN, 2016: A/A) 
Ademais, em se tratando de uma proposta de reparação de natureza financeira, outro questionamento que se abre é: até que ponto esta proposição influencia nos testemunhos dados nas audiências? Como o ambiente construído nas audiências da CNV podem influir no sentido de um discurso de vitimização? Quem é realmente o sujeito da CNV? Várias questões se abrem e começam a delinear caminhos os quais a pesquisa deve trilhar.

\section{A arrepsia como conclusão}

O debate contemporâneo acerca da CNV, no Brasil, deve ser compreendido em uma perspectiva mais ampla, uma vez que, assim como em outros países da América Latina, o estabelecimento desta comissão se deu a partir de reivindicações de muitos atores sociais, principalmente pessoas atingidas pela ditadura, familiares de vítimas, grupos sociais que sofreram algum tipo de violação, entre outros. Contudo, também devemos evidenciar que, por se instalar quase um quarto de século após o final da ditadura militar, as experiências de outras comissões - principalmente latino americanas puderam ser tomadas como referências na elaboração de seus procedimentos. Todavia, isso não exclui a ocorrência de divergências acerca da realização, dos procedimentos e finalidades da mesma.

Em vários momentos o Relatório Final da CNV faz menção às experiências das Comissões na Argentina, Chile, Paraguai, Peru, bem como da África do Sul, entre outras. Nesse sentido, depreende-se que um grande arcabouço metodológico e procedimental deva ter servido como referência, como forma de refletir acerca dos problemas enfrentados e elaborar novas respostas, assim como orientar-se por práticas que se apresentaram de maneira eficiente.

Tomando por exemplo o caso argentino, com o fim da ditadura militar, em 1983, este país acaba por desenvolver um conjunto de práticas que passam a tecer uma luta política, jurídica e simbólica contra o esquecimento das cerca de 30 mil vítimas do terrorismo de Estado (1976-83). Uma luta pelos Direitos Humanos passou a ser travada, objetivando a criminalização do regime militar e a punição dos envolvidos. Nesse sentido, 
a tessitura de uma série de ações foram bastante fecundas, e, embora a lei de Anistia tenha sido decretada pelo presidente Carlos Menen (1990), a articulação de uma memória social acerca do passado ditatorial ainda se percebe com bastante clareza em diferentes posturas políticas e movimentos sociais na contemporaneidade.

O historiador alemão, Andreas Huyssen, ao analisar o caso argentino, postula que:

A memória da ditadura foi crucial para o sucesso da transição para a democracia na Argentina. Podemos dizer que a Argentina de hoje, apesar de suas dificuldades econômicas, tem os mais intensos debates sobre a memória entre os países latino-americanos que foram atormentados pelas campanhas militares de repressão, tortura e assassinatos nas décadas da Guerra Fria posteriores aos anos 1960 - mais intensos que os do Brasil, Uruguai, Chile ou Guatemala. Esse 'sucesso' certamente foi um dos fatores que mantiveram os militares nos quartéis durante a queda livre econômica e social do país desde 2001. (HUYSSEN, 2014: 161)

Findado o período de governo militar na Argentina, quase que imediatamente, iniciou-se a articulação de uma série de ações que visavam instaurar a punição de envolvidos em torturas, assassinatos, desaparecimentos e vários outros tipos de violência perpetrados pelo Estado de exceção. Neste ínterim, ao analisar a consolidação de uma determinada memória acerca das vítimas e do próprio regime político, Huyssen acena para um conjunto de situações nas quais o esquecimento público atrelou-se a um discurso politicamente desejável da memória, tornando-se necessário para que uma série de reivindicações culturais, jurídicas e simbólicas pudessem ser consolidadas. Assim, o autor assevera que "Na Argentina, foi uma dimensão política do passado - a saber, as mortes causadas pela guerrilha urbana armada da década de 1970 - que teve de ser 'esquecida' (silenciada, desarticulada) para permitir um consenso nacional da memória em torno da figura vitimada dos desaparecidos" (HUYSSEN, 2014: 160).

A partir dos diálogos teóricos estruturados pelos apontamentos de Andreas Huyssen, bem como outros autores, uma série de questões, operadas num plano comparativo à realidade brasileira pós-ditadura militar (1964-85) começaram a surgir: seria preciso esquecer-se de algo para lembrar-se? Quem foram as vítimas da ditadura e quais suas trajetórias de vida? Como elas lidaram com sua situação ao largo desse período? 
O caminho trilhado até o momento e as questões acima listadas acenam para os direcionamentos futuros que esta pesquisa deve tomar. Nesse sentido, o enfoque voltarse-á para a produção de novas entrevistas com os depoentes nas audiências da CNV, com o objetivo de compreender de modo mais amplo tanto seus testemunhos como o trabalho da própria comissão. Uma leitura inicial dos relatórios e depoimentos dá a impressão de que o foco principal dos trabalhos centrou-se numa absolutização dos testemunhos, atribuindo a estes um estatuto de verdade histórica, bem como, em alguns momentos "pinçando" ideias e informações que se adequem à memória que se objetiva construir e nos levando a questionar quem realmente é o sujeito da Comissão da Verdade: os indivíduos, o Estado, os militares, a violência?

Nesse sentido, procuramos compreender como e se as ações desenvolvidas pela CNV em seus trabalhos conseguem dar conta de promover um processo de individuação e subjetivação, permitindo que os depoentes, na perspectiva de Alain Touraine (2009), se tornem sujeitos e promovam uma reflexão de si para si e na relação para com o outro. Pois somente nos tornamos plenamente sujeitos aceitando como ideal reconhecer-nos e fazer-nos reconhecer enquanto indivíduos - tornando-nos seres individuados, que lutam, protegem e constroem sua singularidade, dando sentido a sua existência através de seus atos de resistência.

Não obstante a esse processo de individuação e subjetivação, tem-se uma dimensão contemporânea da memória e do passado como elementos promotores de uma práxis que promova os direitos humanos no presente, questionando estruturas sociais e políticas que primam pela manutenção de desigualdades e injustiças, bem como violações contemporâneas, nas palavras do próprio Touraine:

Não vejo por que a defesa dos direitos humanos, sociais e culturais de cada indivíduo, que só podem ser defendidos coletivamente, implicaria a indiferença quanto à situação dos outros. (...), eu especifico que a defesa dos direitos pessoais, como sempre, alimenta a ação coletiva contra todos os privilégios, (...). Não tenho qualquer razão para me distanciar da tradição secular que uniu o respeito do indivíduo com as lutas por todas as liberdades coletivas. (TOURAINE, 2009: 191) 
Conforme a concepção do autor faz-se necessário que os sujeitos resguardem sua memória, mas que a possam atrelar ao pensamento racional, à liberdade e identidade cultural. Pois, assim, a democracia conseguirá garantir o respeito às diferenças individuais e a pluralidade, bem como a práticas participativas e colaborativas sociais e políticas.

Por fim, devemos pensar a memória a partir da necessidade de problematizar a experiência humana em tempos de violência e crise. Muitas narrativas visualizadas até o momento trazem consigo não apenas a memória, mas também o esquecimento e uma forte tendência retórica, as quais parecem ser analisadas sob uma única perspectiva nos trabalhos da CNV. Nesse sentido, não está em jogo apenas o que é lembrado e o que é esquecido, mas também o trabalho de seleção do que pode ou não ser lembrado, bem como a maneira pela qual isso deve ser lembrado e narrado, fazendo com que experiências de privação, violação, perdas, mortes, entre outras, assumam sentido, justificando sua trajetória e legitimando aquilo que se reivindica.

\section{Referências}

Brasil. Comissão Nacional da Verdade. Relatório / CNV - Recurso eletrônico. - Brasília: CNV, 2014. - Volumes 1, 2 e 3 (in: http://www.cnv.gov.br/). Acesso em: 18/11/2016.

BERGER, Peter Ludwig. O dossel sagrado: elementos para uma teoria sociológica da religião. trad. J. C. Barcellos, S. Paulo: Ed. Paulinas, 1985

CASADEI, Eliza. Jornalismo e Ressignificação do Passado: Os fatos históricos nas notícias de hoje. 2010. Dissertação (Mestrado em Ciências da Comunicação). São Paulo: USP, 2010.

CIRIO, Dom Armando. Arquidiocese de Cascavel: Ontem e Hoje - 1978-1983. Assoeste, Cascavel, 1983;

COLODEL, Augusto. Obragens \& Companhias Colonizadoras - Santa Helena na História do Oeste Paranaense até 1960. Santa Helena: Prefeitura Municipal, 1988;

CONRADI, Carla Nacke. Memórias do Sótão: vozes de mulheres na militância política contra a ditadura no Paraná (1964-1985). 2015. Tese (Doutorado em História) Curitiba: UFPR, 2015. 


\section{DEPOIMENTOS COMISSÃO DA VERDADE - AUDIÊNCIA PÚBLICA CNV CASCAVEL}

http://projetos.unioeste.br/webradio/index.php?option=com_content\&view=article\&id= 191:audiencia-publica-da-comissao-estadual-da-verdade-unioeste-cascavel-nos-dias-20-e21-de-marco-acompanhem-os-audios\&catid=40:eventos. Acesso em 12/10/2015.

FICO, Carlos. Versões e controvérsias sobre 1964 e a ditadura militar. Revista Brasileira de História, vol. 24, n 47. São Paulo, 2004.

HALBWACHS, Maurice. A memória coletiva. São Paulo, Centauro: 2006.

HARTOG, François. Regimes de historicidade: presentismo e experiências do tempo. Belo Horizonte: Autêntica, 2013.

HARTOG, François. Tempo e Patrimônio. Varia História, Belo Horizonte, vol $22 \mathrm{n}^{\circ}$ 36: $\mathrm{p}$. 261-273, jul/dez 2006. http://www.scielo.br/pdf/vh/v22n36/v22n36a02.pdf . Acesso em: 06/05/2017.

HUYSSEN, Andreas. Culturas do passado-presente: modernismos, artes visuais, políticas da memória. Rio de Janeiro: Contraponto/Museu de Arte do Rio, 2014.

MEZAROBBA, Glenda. Um acerto de contas com o futuro - a anistia e suas conseqüências: um estudo do caso brasileiro. São Paulo, Humanitas/Fapesp, 2006.

MAGALHÃES, Marion Brepohl de. Paraná: política e governo. Curitiba: SEED, 2001.

NIEDERAUER, Ondy Hélio. Toledo no Paraná - História de um latifúndio improdutivo, sua reforma agrária, sua colonização, seu progresso. Toledo. Grafo-Set. 1992;

NORA, Pierre. Entre memória e História: a problemática dos lugares. Projeto História. São Paulo, PUC-SP, n. 10, pp. 7-28, dez. 1993.

PALMAR, Aluízio. MEMÓRIA, MEDO E ESQUECIMENTO: a ditadura civil-militar na Região Oeste do Paraná, fatos e reflexões sobre a pesquisa no Arquivo da Delegacia da Policia Federal de Foz do Iguaçu (p. 145-153). In: Silva, Carla. [et. al]. Ditaduras e Democracias: Estudos sobre poder, hegemonia e regimes políticos no Brasil (1945-2014). Porto Alegre, FCM Editora, 2014.

PAWELKE, J. Ficando rico no Oeste do Paraná. Marechal Cândido Rondon: Igreja Martin Luther, 1970

POLLAK, Michael. Memória, Esquecimento e Silêncio. Estudos Históricos, Rio de Janeiro, vol. 2, n. 3, 1989, p. 3-15. http://www.uel.br/cch/cdph/arqtxt/Memoria_esquecimento_silencio.pdf. Acesso em 06/05/2017. 
PORTELLI, Alessandro. A Filosofia e os Fatos. Revista Tempo, Rio de Janeiro, vol. 1, nº 2, 1996, p. 59-72.

PORTELLI, Alessandro. Tentando aprender um pouquinho. Algumas Reflexões sobre ética na História Oral. Projeto História, ${ }^{\circ}$ 15, Revista do departamento de História da PUC SP, São Paulo: Abril de 1997, p. 13-33.

RICOEUR, Paul. A memória, a história, o esquecimento. Campinas: Editora da Unicamp, 2007.

ROSIN, Valdemar. Entrevista realizada em 26 de março de 2016. Arquivo do Autor (A/A). SAATAKAMP, Venilda. Desafios, lutas e conquistas: História de Marechal Cândido Rondon. Cascavel: Assoeste, 1984.

SARLO, Beatriz. Tempo Passado. Cultura da Memória e guinada subjetiva. São Paulo: Companhia da Letras, 2007.

SAUNDERS, Rebecca. Sobre o intraduzível: sofrimento humano, a linguagem de direitos humanos e a Comissão de Verdade e Reconciliação da África do Sul. Revista Internacional de Direitos Humanos, São Paulo, v. 5, n. 9, Dez. 2008.

http://www.scielo.br/scielo.php?script=sci_arttext\&pid=S1806-64452008000200004. Acesso em 18/11/2016.

SCHLACHTA, Marcelo Hansen. O MST e a Questão Ambiental: Uma Cultura Política em Movimento. 2008. Dissertação (Mestrado em História) MCR: Unioeste, 2008.

SCOTT, James C. A dominação e a arte da resistência: Discursos Ocultos. Letra Livre. Lisboa, 2013.

SELIGMANN-SILVA, Márcio. Apresentação da questão. In: SELIGMANN-SILVA, Márcio. org. História, memória, literatura. Campinas: Ed. Unicamp, 2003.

SELIGMANN-SILVA, Márcio. Testemunho e a política da memória: o tempo depois das catástrofes. Projeto História, São Paulo: PUC, n. 30, p. 71-98, jun. 2005.

http://revistas.pucsp.br/index.php/revph/article/view/2255/1348. Acesso em: 07/08/2016.

SPERANÇA, Alceu A. Cascavel: A História. Curitiba. Lagarto, 1992.

TOURAINE, Alain. Pensar Outramente: 0 discurso interpretativo dominante. Rio de Janeiro: Vozes, 2009.

THOMSON, Alistair. Recompondo a memória: questões sobre a relação entre a história oral e as memórias. Revista do Programa de Estudos Pós-Graduados em História do Departamento de História da PUC/SP. São Paulo, n.15, abr. 1997, p.51-84. 
THOMPSON, Edward Palmer. A economia moral revisitada. In: THOMPSON, Edward Palmer. Costumes em comum. Estudos sobre a cultura popular tradicional. São Paulo: Companhia das Letras, 1998.

WELZER, Harald; MOLLER, Sabine; TSCHUGGNALL, Karoline. Mi abuelo no era nazi. El nacionalsocialismo y el Holocausto em la memória familiar. Buenos Aires: Prometeo Libros, 2012. 